\title{
Литературоведение
}

УДК 821.161 .1

DOI: $10.21779 / 2542-0313-2016-31-2-20-25$

\section{Т.В. Швецова}

\section{«План мира» и поступок героя в повести А.И. Герцена «Легенда»}

Северный (Арктический) федеральный университет имени М.В. Ломоносова; 164500, Северодвинск, ул. Воронина, 6; t.shvetsova@narfu.ru

Статья посвящена специфике художественной модели мира, представленной в повести А.И. Герцена «Легенда». Особое внимание уделяется понятиям «герой» и «поступок», которые являются фундаментальными категориями онтологической концепции отечественного философа и литературоведа М.М. Бахтина.

Автор обращается к некоторым научным и критическим работам М.Н. Климова, Л.В. Крестова, И.С. Нович, Е.А. Петухова и других. Эти роботы посвящены исследованию отдельных аспектов повести А.И. Герцена «Легенда». Отмечается, что в целом данное произведение изучено в недостаточной степени: так, в частности, исследователями не были детально рассмотрены модель мира и образ героя в повести.

В статье проанализированы факторы, побудившие А.И. Герцена обратиться к художественной переработке житийного текста о св. Феодоре, а также рассмотрены важнейшие источники исследуемой повести. Автор определяет основные тенденции русской литературы 30 40-х гг. XIX века: критическое восприятие и отражение действительности, идея десакрализации мира, утрата представлений об эпическом герое.

Формулируется вывод о том, что в «Легенде» А.И. Герцена представлена сложная модель мира, которая в структурном плане состоит из следующих плоскостей: мир большой и малый, мир горний и дольний, мир дальний и ближний. Структурные элементы, участвующие в построении модели мира, получают особое семантическое наполнение. На границе двух миров возникает герой-праведник: человек, несущий деятельное начало и совершающий поступок, ощущая собственную подчиненность Божественной воле, во имя служения миру.

Ключевые слова: литературный герой, поступок, модель мира, А.И. Гериен.

Духовные искания русских писателей первой половины XIX века были неразрывно связаны с представлениями об определенной картине мира и положении человека в ней. С этой точки зрения особого внимания заслуживают эстетические и философские установки А.И. Герцена.

Творческое наследие писателя довольно разнообразно и определяется широким диапазоном социальных, философских, политических проблем, к которым обращается автор. Как отмечает И.С. Нович, «талант Герцена-художника един с его талантом мысли, стремившейся соединить философию, историю и современность, философию природы, социологию утопического социализма...» [9, с. 362].

В данной статье раскрывается специфика художественной модели мира, представленной в повести А.И. Герцена «Легенда», это выявляются социальнонравственные аспекты художественной концепции молодого писателя. При этом особое внимание уделяется понятиям «герой» и «поступок», которые являются фундаментальными категориями онтологической концепции отечественного философа и литературоведа М.М. Бахтина. 
Подчеркнем, что, несмотря на постоянное внимание исследователей к художественному творчеству А.И. Герцена, рассматриваемое нами произведение до сих пор не до конца изучено. Отдельные аспекты «Легенды» были проанализированы в работах Л.Я. Гинзбург [3], М.Н. Климовой [4; 5], Л.В. Крестовой [6], Е.А. Петуховой [10] и др. Необходимо отметить, что исследователи учитывают биографические факторы создания повести, а также обращают внимание на трансформацию житийных канонов и интертекстуальные связи «Легенды». При этом концептуальные художественные образы детально не рассматриваются.

Повесть «Легенда», написанная в 1835 г. в Крутицких казармах и впоследствии переработанная в Вятке, относится к «ученическим» произведениям А.И. Герцена и является своеобразным отражением его ранних концептуальных представлений о мире и человеке. Выявляя специфику ранних текстов писателя, Л.Я. Гинзбург отмечает: «Это произведения литературно слабые, исполненные романтических шаблонов и наивной патетики. И живут они не в отдельности, но только в том общем, стремительном потоке, какой представляет собой романтическое сознание юного Герцена» [3, с. 7-8].

«Легенда» представляет собой опыт художественной обработки агиографического рассказа о покаянии согрешившей женщины, скрывающейся от прошлой жизни под видом инока мужского монастыря. Сюжет о жизни преподобной Феодоры привлек внимание молодого писателя: трогательная легенда была воспринята А.И. Герценом как пример духовных стремлений человека к духовным идеалам и служению миру.

Примечательно, что непосредственное обращение молодого писателя к агиографическому сюжету было обусловлено знакомством А.И. Герцена со сводом Димитрия Ростовского. При этом важно обозначить обстоятельства, при которых происходило данное знакомство: Герцен находится под арестом в Крутицких казармах и ожидает приговора. Нам видится необходимым подчеркнуть, что подобные обстоятельства, образующие кульминационный момент в жизни писателя, настраивали его на пересмотр собственных жизненных ориентиров и ценностных установок. Таким образом, «уроки христианского вероучения падали на благодарную почву. Неведомый доселе мир агиографии поразил молодого писателя силой и напряженностью духовных устремлений, что резко контрастировало с пошлой обыденностью окружающей его современности» [5, c. 194].

На наш взгляд, целесообразно обозначить интертекстуальные связи и основные источники, к которым А.И. Герцен обращался при создании «Легенды»: жизнеописание святой Феодоры в Четиих-Минеях, сюжеты из Ветхого Завета, апокрифические тексты. Кроме того, как справедливо отмечает в своем исследовании Е.А. Петухова, «в тексте (А.И. Герцена. - Т.Ш.) неоднократно встречаются отсылки к высказываниям Гете и его автобиографическим произведениям» [10, с. 118].

Подобные произведения, по мнению некоторых современников А.И. Герцена, обладали ярко выраженным метафорическим потенциалом и позволяли писателям утверждать новые основания в искусстве.

Подчеркнем, что изменения, произошедшие в художественном сознании русских писателей 30-40-х годов XIX века, обусловили процесс формирования новой модели мира и концепции героя в литературе. Современные исследователи называют данный период состоянием «ожидания героя»: «Совершенно очевидно, что героя не просто «не случилось» в этот момент в русской литературе, его в принципе не могло быть, его не предполагала вся выстраиваемая система новых отношений» [8, с. 202].

Новая модель мира возникает как своеобразный ответ на ключевую проблему времени, которая актуализируется в вопросах уточнения пределов личной свободы че- 
ловека и идее десакрализации мира. Примечательно, что А.И. Герцен одним из первых показал в собственных сочинениях соприсутствие в мире двух плоскостей: социальной (семья, служение, учение) и высшей (плоскость иного порядка). При этом малый мир, отражающий социальный миропорядок, оказывается свободным, что позволяет героям А.И. Герцена предпринять попытку превратить свой социальный мир в счастье.

Отметим, что в отечественном литературоведении одним из самых значимых трудов, посвященных проблеме героя, является работа М.М. Бахтина «К философии поступка», в которой автор формулирует основные положения собственной онтологической концепции [1].

Одним из ключевых понятий, на которое обращает внимание исследователь, становится «поступок» - своеобразная призма, высвечивающая архитектонику мира. Герой литературного произведения всегда совершает «активно-ответственный поступок», что позволяет ему занимать «осевое положение» в произведении [1, с. 7-32].

Обратимся к повести А.И. Герцена. Фабула «Легенды» основывается на традиционной для агиографических текстов модели «грехопадение - раскаяние - страдание искупление - спасение» и мотивах «неузнавания» и «перевоплощения». Следовательно, развитие сюжета определяется нравственными противоречиями героини, которая совершила прелюбодеяние и стремится искупить этот грех посредством ухода в монастырь. При этом развязка житийного сюжета становится возможной за счет второстепенного сюжета, связанного с образом мужа Феодоры: героиня принимает ответственность за чужой грех, получает прощение и удостаивается святости, но муж находит потерянную жену лишь после ее смерти в келье мужского монастыря.

Н.И. Николаев в статье «Литературный герой в мире его поступка» приходит к важному выводу: «...этически значимым является не результат поступка, его осязаемый продукт - в художественном целом он может быть вовлечен в сферу авторской оценки поступка, а сам процесс свершения, мотивы его исхождения, неслучайность его начала, нравственные истоки долженствования поступающего» [7, с. 174].

Мы считаем, что вопрос о границах человеческой свободы, имеющий важное значение для понимания концепции А.И. Герцена, актуализируется за счет композиционного плана «Легенды». В первой главе, своеобразном предисловии, раскрываются условия, при которых была создана повесть: узник, находящийся в заключении, передает свои мысли и настроения. Он произносит: «Тюрьма не есть уединение, чувство, что человек выброшен из общества, отрешен от всех его условий, - давит, душа сосредоточивается, занимает наименьшее пространство, уменьшается» [2, с. 81]. При этом тюрьму необходимо воспринимать как символ ограничения свободы, созданный непосредственно самим человеком.

Иначе представлена история Феодоры, которая добровольно выбирает заключение в монастыре. Ощущение невыносимости собственного греха и раскаяние толкает Феодору на вполне осознанный поступок - уход из мира и прежней жизни, что впоследствии приводит не только к изменению статуса героини, но и к нравственному перерождению. Ответственность героини определяется решением удалиться из большого мира: не желая множить зло в мире и нарушать установленный Богом миропорядок, Феодора удаляется от него, но в то же время служит ему из благих побуждений, ощущая замысел Бога о мире. Следовательно, истинный поступок героини состоит не столько в реализации собственной воли, сколько в подчинении божественной воле. Она удаляется из мира, чтобы сделать его лучше и замолить грехи, совершаемые людьми.

Согласимся с точкой зрения Е.А. Петуховой, которая отмечает следующее: «Автор не случайно обращается к фигуре женщины, переодевшейся в мужчину. С одной 
стороны, образ грешницы, превратившейся в святую, связан с идеальным образом Вечной Женственности <...>. С другой, временное «превращение» такой женщины в мужчину приближает недоступный идеал к земному миру» [10, с. 122]. По всей вероятности, чтобы исправить земной грубый мир, очистить его.

На наш взгляд, Феодорой избрана самая тяжелая форма «ухода» из мира, заключающаяся в религиозном самоотречении, которое неразрывно связанно с идеей служения Богу. Подчеркнем, что монастырская жизнь налагает ряд ограничений и запретов и связана с добровольным самопожертвованием героя и исполнением заповедей: переступив порог святой обители, Феодора перестала принадлежать самой себе и вверила свою судьбу Божьей воле. Таким образом, героиня, совершившая грех и покинувшая прежний мир, оказывается носителем деятельного начала. Ее подвиг - в смирении, в способности подчиниться замыслу Творца.

Поступок Феодоры не только раскрывает образ героини, но и позволяет выявить специфику художественной модели мира, представленной в исследуемом произведении. На наш взгляд, в «Легенде» А.И. Герцена представлена сложная модель мира, которая в структурном плане состоит из следующих плоскостей: мир горний и дольний, мир дальний и ближний. Обладая различным семантическим наполнением, данные элементы в совокупности отражают концептуальные взгляды молодого писателя на мир и человека.

Композиция повести предполагает раскрытие нравственной дихотомии. Перед нами два типа героев: герой-повествователь, заключенный, силящийся отыскать присутствие в земном мире божественной Воли, и Феодора, пережившая нравственную метаморфозу, ощущающая божественное начало в мире.

Подчеркнем, что план мира становится более отчетливым благодаря перемещениям Феодоры: движение в физическом смысле (непосредственный переход из Александрии в мужской монастырь) и движение в духовном смысле (отказ от прежней жизни и служение Богу). Подобный переход, связанный с раскаянием и испытаниями Феодоры, позволяет ей приобрести новый статус и изменить систему жизненных ориентиров.

Вместе с тем меняется определенная принадлежность героини к тому или иному пространству: добровольно отказываясь от земного мира, Феодора делает сознательный выбор, тем самым она совершает поступок, смысл которого в отказе от собственной самости. Она осознает, что есть порядок земного существования и есть какой-то другой Порядок, куда воля человека не распространяется. Она уходит из мира, чтобы служить миру, сделать его лучше, уменьшить зло. «Он отрешался от мира земного, он слышал глас Иисуса, призывавший его туда, в обитель любви и надежды, туда, где поют бога чистые ангелы, где души праведных его видят, где между ними и покаявшиеся грешники...» $[2$, с. 87].

На наш взгляд, именно на границе двух пространственных плоскостей (мир земной и мир высший) Феодора становится носителем праведного мышления, что в целом меняет ее образ. Отметим, что «инаковость» героини также становится очевидной для окружающих. Так, например, молодая египтянка, видя Феодора (Феодору), размышляет: «...освещенный последним остатком света, окруженный мраком, Феодор казался ей чем-то принадлежащим нездешнему миру; она думала видеть архангела, принесшего благую весть деве иудейской...» [2, с. 98].

Следовательно, благодаря образу героя-праведника, являющегося носителем деятельного начала и мыслящего христианскими категориями, пространственные элементы, которые структурируют модель мира, приобретают вполне определенные значения. Так, земной мир представлен как средоточие человеческих пороков и грехов, которые в 
целом нарушают созданный Богом миропорядок. В то же время плоскость Высшего порядка не доступна большинству: раскаяние и религиозное самоотречение позволяют Феодоре быть сопричастной божественному замыслу о мире.

Удалившись из большого мира и посвятив себя служению ему, героиня совершает активно-ответственный поступок, который приводит не только к духовному перерождению Феодоры, но и к изменению мира в целом. Разрыв связей с прежним малым социальным пространством (домашняя жизнь, семья, малый круг действий) трансформирует сознание героини, делает ее истинным носителем христианского мироощущения.

В заключение подчеркнем, что «Легенда» А.И. Герцена отражает философские воззрения молодого писателя и актуализирует важнейшие вопросы нравственного, социального и религиозного характера. При этом важнейшими концептами, образующими идейно-тематическое ядро произведения и раскрывающими его метафорический смысл, становятся «герой», «поступок» и «мир».

\section{Литература}

1. Бахтин М.М. К философии поступка // Собр. соч.: в 7 т. - М.: Русские словари; Языки славянской культуры, 2003. - Т. 1. - С. 7-68.

2. Гериен А.И. Легенда // Собр. соч.: в 30 т. - М.: Изд-во Академии наук СССР, 1954. - T. 1. - C. 81-106.

3. Гинзбург Л.Я. Автобиографическое в творчестве Герцена // Литературное наследство: Герцен и Огарев в кругу родных и друзей. - М.: Наука, 1997. - Т. 99. - С. 7 54.

4. Климова М.Н. К изучению житийной традиции в русской литературе XXI$\mathrm{XX}$ вв. // Вестник Томского государственного педагогического университета. - Томск: Изд-во ТПГУ, 2009. - № 4. - С. 156-161.

5. Климова М.Н. Ранние пересказы православных житий: «Легенда» А.И. Герцена и «Мария Египетская» И.С. Аксакова. - Барнаул; Рубцовск, 2009. - С. 189-198.

6. Крестова Л.В. Источники «Легенды о св. Феодоре» А.И. Герцена // Памяти П.Н. Сакулина: сборник статей. - М.: Никитинские субботники, 1931. - С. 116-119.

7. Николаев Н.И. Литературный герой в мире его поступка // Дискуссия. - Екатеринбург, 2012. - № 3 (21). - С. 173-178.

8. Николаев Н.И., Швецова T.В. Русский литературный герой 30-40-х годов XIX века и проблема поступка // Фундаментальные исследования. - М., 2014. - № 3 (1). - C. 201-204.

9. Нович И.С. Молодой Герцен: Страницы жизни и творчества. - М.: Советский писатель, 1986. - 362 с.

10. Петухова E.A., Козлов А.Е. Повесть А.И. Герцена «Легенда»: сюжет, повествование, интертекст // Вестник НГПУ. - Новосибирск: Изд-во НГПУ, 2013. - № 3. C. 117-127.

Поступила в редакцию 27 июня 2016 г. 
UDC 821.161 .1

DOI: $10.21779 / 2542-0313-2016-31-2-20-25$

\section{«World model» and the character's deed in A.I. Herzen`s «Legend» T.V.Shvetsova}

Northern (Arctic) Federal University named after M.V. Lomonosov; 164500, Russia, Severodvinsk, Voronin st., 6; t.shvetsova@narfu.ru

This article studies some features of the artistic world model, represented in A.I. Herzen's story entitled «Legend». Particular emphasis has been placed on the concepts «character» and «deed», which are the fundamental ontological categories in M.M. Bakhtin`s literary and philosophical conception.

The author refers to some scientific and critical works devoted to the study of particular aspects in A.I. Herzen's «Legend»: M.N. Klimova, L.V. Krestova, I.S. Novich, E.A. Petukhova and others. It's noted that in general this work is studied insufficiently: researchers have not considered in detail the world model and the image of the character in the story.

The article analyses the factors that prompted A.I. Herzen to resort to the literary adaptation of St. Theodor's hagiography. The author also considers the most important sources of Herzen's «Legend» and defines the basic tendencies in Russian literature of 30-40-ies of the XIX century: critical perception and reflection of surrounding reality, loss of the complete ideas about the epic hero, the idea of desacralization of the world, appeal to the spiritual literature and traditional religious plots.

The author concludes that A.I. Herzen's «Legend» presents a complex model of the world, structurally consisting of the following models: a small world and a big world, a heavenly world and an earthly world, a far world and a near world. The structural elements, constituting the model of the world acquire some specific semantic content here. There is a real righteous character on the border of two worlds: the righteous man carrying some active start and performing a deed, following the divine will for the good of the world.

Keywords: literary hero, deed, world model, A.I. Herzen.

Received 27 June, 2016 